INTERNATIONAL JOURNAL OF RESEARCH IN PHARMACY AND CHEMISTRY

Available online at www.ijrpc.com

Research Article

DOI: https://dx.doi.org/ 10.33289/IJRPC.10.1.2020.10(8)

\title{
FORMULATION AND EVALUATION OF MOUTH DISSOLVING FILMS FOR CARDIOVASCULAR DISEASE
}

\author{
Manasa Vayya* and K. Abbulu \\ Department of pharmaceutics, CMR College of Pharmacy, \\ Kandlakoya (V), Medchal road, Hyderabad-501 401, India.
}

\begin{abstract}
The main aim of the current study is to develop Mouth dissolving films (MDFs) of Ramipril which is an anti-hypertensive agent used to cardiovascular diseases. Five formulations (E1, E2, E3, E4, E5) were prepared by using HPMC E15 and PVA as polymers, PEG 400 as plasticizer, aspartame as sweetening agent, citric acid as saliva stimulatingz agent and orange as flavoring agent by following solvent casting method. The films prepared shows quick onset of action, increases bioavailability by avoiding hepatic first pass metabolism and is administered without the help of water. Formulation E2 showed drug release of $98.2 \%$ within 3 minutes and was found to be stable under suitable stability conditions. From the results of evaluation parameters of films suggest that mouth dissolving films of Ramipril can be an impressive and innovative approach for the treatment of cardiovascular disease like heart failure, heart attack and myocardial infarction.
\end{abstract}

Keywords: Mouth dissolving films, Ramipril, HPMC E15, PVA, solvent casting method.

\section{INTRODUCTION}

Most of the pharmaceutical researchers are mainly focusing on the oral dosage form which gives quick onset of action by offering rapid drug release. Mouth Dissolving Films (MDFs) is an innovative and impressive drug delivery system which increases patient compliance. MDFs deliver the drug systematically via sublingual or buccal route of administration and additionally for local action ${ }^{1}$. MDFs constitute a thin film which when positioned on the tongue gets wet by saliva and moistens rapidly, and then film dissolves and disintegrates within seconds to supply the drug for absorption. When compared to capsules and different dosage forms, MDFs are advantageous because film dissolves within seconds and shows onset of action. MDFs increases bioavailability, shortens the onset of time, prevents first pass metabolism. Fast dissolving drug delivery is the maximum advanced form as it improves efficacy of drug, flexibility, disintegration and dissolution ${ }^{1}$.

Zengen Inc developed this new drug delivery system, which is a medicated oral film structured as proprietary bilayer system ${ }^{1}$. These films contain water soluble hydrocolloids such as HPMC, pullalan, pectin, carboxymethyl cellulose, an effective dose of the active agent, other excipients which include palsticizers, preservatives, flavoring agents and saliva stimulating agents.

The research studies provided a significant advantage in preventing many CVD outcomes in patients with high risk of vascular disease and diabetes which can be treated by using angiotensin-converting enzyme (ACE) inhibitor I.e. Ramipril. It showed promising results in reducing cardiovascular events, heart attack, heart failure, heart stoke. Ramipril has an impressive track record of improving cardiovascular outcomes and have to be considered a favored agent among the ACE inhibitors. The risk of causing death was decreased among the humans treated with Ramipril. Ramipril is favored in the study due to its anti-hypertensive activity which is used to treat excessive blood pressure, heart failure and diabetic kidney disease and to prevent cardiovascular events ${ }^{2}$.

\section{MATERIALS AND METHODS}


Ramipril was obtained as a gift sample from Aurobindo Pharma Limited Unit-III, Bachupally, Hyderabad, India. HPMC E15, PVA, Sodium Starch glycolate. Citric acid, orange was obtained from Research lab, Aspartame, PEG-400 was obtained from Sd Fine Limited.

\section{Preparation of Mouth Dissolving Films (MDFs)}

MDFs were prepared by using solvent casting method $^{3}$. In this method, polymers such as HPMC E15 and PVA are soaked overnight. Sodium starch glycolate and all other excipients such as aspartame, PEG 400, like citric acid and orange flavor were added to polymer solution and stirred at $1000 \mathrm{rpm}$ for 1 hour. Ramipril dissolved in few $\mathrm{ml}$ of ethanol was added to polymer solution while stirring and stirred at $100 \mathrm{rpm}$ for $30 \mathrm{~min}$. The obtained solution is then kept aside for few minutes till the entrapped air bubbles were removed. The solution was poured on a glass petriplate (diameter $6.5 \mathrm{~cm}$ ) and kept for drying for $4-5$ hrs at $45^{\circ} \mathrm{C}$. The film was removed gently from the petriplate, checked for any deformity and cut into the required size and shape to deliver the equivalent dose $\left(2 \times 2 \mathrm{~cm}^{2}\right)$ each film. The obtained films were packed in aluminium foils and stored in a desiccator at $30-35 \%$ RH. (Table 1)

\section{RESULTS AND DISCUSSION}

\section{Calibration curve of Ramipril in pH 6.8 phosphate buffer}

Standard plot of Ramipril was prepared by using $\mathrm{pH} 6.8$ phosphate buffer. $100 \mathrm{mg}$ of Ramipril was accurately weighed and transferred it into volumetric flask $(100 \mathrm{ml})$. To this, small quantity of $\mathrm{pH} 6.8$ phosphate buffer was added to dissolve the drug and then the solution was made up to $100 \mathrm{ml}$ using $\mathrm{pH} 6.8$ phosphate buffer. The concentration of drug was $1000 \mu \mathrm{g} / \mathrm{ml}$. This is considered as stock solution (A). From stock solution, A dilutions were made to obtain concentration $10 \mu \mathrm{g} / \mathrm{ml}$.

From this concentration $(10 \mu \mathrm{g} / \mathrm{ml})$, appropriate dilutions $2,4,6,8,10 \mu \mathrm{g} / \mathrm{ml}$ was made and absorbance was measured by using UVSpectrophotometer at $209 \mathrm{~nm}^{4}$. (Table 2) (Figure 1)

\section{Drug-Excipient Compatibility Studies}

Drug-excipient compatibility study was performed by Fourier Transform Infrared (FTIR) Spectroscopy. The characteristic peaks were determined by FTIR-spectra, which identified the purity of drug. The compatibility study between the drug and the polymers was carried out using FTIR spectra. The peak numbers of the Ramipril exhibiting $\mathrm{Ar}-\mathrm{H}, \mathrm{C}-\mathrm{H}$, $\mathrm{C}=\mathrm{O}$, C-O stretching were observed ${ }^{5}$. (Table 3) (Figure 2 and Figure 3)

\section{EVALUATION \\ Appearance}

All the formulated films were transparent, homogenous, thin and soft.

\section{Weight uniformity}

Ten different films from each formulation were taken and weighed on weighing balance ${ }^{6}$. It was found to be in a range of $22.5 \pm 0.30 \mathrm{mg}$ to $32 \pm 0.60 \mathrm{mg}$. All the films were found to be uniform. (Table 4)

\section{Thickness uniformity}

The thickness was measure by using micrometer or screw gauge at different locations of the film ${ }^{1}$. The thickness of the prepared films was found to be in a range of $80 \pm 1 \mu \mathrm{m}$ to $95 \pm 2.5 \mu \mathrm{m}$ indicates that thickness of the films was increased due to the increase in the concentration of the polymers. (Table 4)

\section{Folding endurance}

Folding endurance was determined by repeatedly folding a film at the same place till it break. The folding endurance values of the prepared films were in range of $110-145^{7}$. The values comply with in the limit 100-150. (Table 4)

\section{Surface $\mathrm{pH}$}

Surface $\mathrm{pH}$ of the films was determined to investigate any side effects because any changes in $\mathrm{pH}$ in vivo, an acidic or alkaline $\mathrm{pH}$ may cause irritation to the oral mucosa. The surface $\mathrm{pH}$ of the films was found to be in a range of 6.5 to 6.8 which comply within the limits $6-7^{1}$. (Table 4)

\section{Percent moisture absorption (PMA) and Percent moisture loss (PML)}

PMA is carried out to inspect the physical strength of the MDFs at high moist situations ${ }^{8}$ and values obtained in a range of 0.5 to $5.2 \%$. PML carried out to inspect the purity of the films at dry situations ${ }^{9}$ and obtained in a range of $0.5-2 \%$. (Table 5 )

\section{Swelling index}

Swelling index of the formulated films were found to be in a range of 12 to $16.9 \%$. High swelling index value of MDFs suggested its suitability for rapid release of Ramipril due to increased absorption of $\mathrm{pH} 6.8$ phosphate buffer $^{4}$. (Table 5)

Drug content uniformity 
Drug content uniformity was performed for all formulated films and was found to be in a range of 93.3 to $98.2 \%$ which indicates uniformity of mixing. Drug content values were within the limit $85-110 \%$ as per IP specifications ${ }^{5}$. (Table 6 )

\section{In-vitro disintegration studies}

In-vitro disintegration time was performed for all formulated films by using petriplate method. The disintegration time was found to be in a range of 20 to 40 seconds. Formulation E2 showed was found to be 20 seconds which took less time to disintegrate when compared to all the formulations. (Table 6)

\section{In-vitro dissolution studies}

In-vitro dissolution studies were performed for all formulations by using USP II dissolution apparatus (paddle type) ${ }^{6}$. Among all formulations, Formulations E2 showed drug release of about $98.2 \%$ in 3 minutes when compared to other formulations. (Table 7) (Figure 4) It was observed that films got hydrated rapidly and began to dissolve the drug with seconds. Hence the rate of drug release was faster because of polymer HPMC E15 which is a water-soluble polymer. Increased concentrations of polymer had resulted in slower dissolution rate.

Further to study the drug release mechanism from Ramipril MDFs, an optimized formulation was selected the data obtained from the invitro disintegration studies, in-vitro dissolution studies and other parameters were fitted into various kinetic models and $R^{2}$ values ${ }^{3}$. The maximum $R^{2}$ value was found to be 0.985 in first-order kinetic model which revealed first order drug release.

\section{Stability studies}

The optimized formulation E2 was subjected to stability studies as $\mathrm{ICH}$ guidelines for 3 months. The films were kept in stability chamber at $25 \pm 2 \circ \mathrm{C}$ at $60 \%$ relative humidity for 3 months ${ }^{3}$. The films were tested for drug content uniformity, In-vitro disintegration test, (Table 8) In-vitro dissolution studies for a period of 1 month and 3 months. (Table 9) (Figure 5). From the results it was observed that, there are no significant changes in the appearance, surface $\mathrm{pH}$ during the stability study.

\section{CONCLUSION}

The objective of the present study has been achieved by preparing MDFs of ramipril. Mouth dissolving films (MDFs) of Ramipril have been successfully prepared by solvent casting method. The optimized formulation (E2) had acceptable characteristics which include physical properties, in-vitro disintegration time is 20 seconds, in-vitro drug release is $98.2 \%$ in 3 minutes. Prepared Ramipril MDFs resulted in improved bioavailability by avoiding first pass metabolism, increase in patient compliance and quick onset of drug action.

\section{ACKNOWLEDGEMENTS}

The authors thank Aurobindo Pharma Limited, Hyderabad, for providing Ramipril as gift sample for this work. I would sincerely thank my guide Dr. K. Abbulu who supported and helped me to accomplish my research work.

Table 1: Formulation Composition Table of Ramipril

\begin{tabular}{|c|c|c|c|c|c|}
\hline Ingredients & E1 & E2 & E3 & E4 & E5 \\
\hline Ramipril (mg) dose per film & 1.25 & 1.25 & 1.25 & 1.25 & 1.25 \\
\hline PVA + HPMC E15 (mg) & $2: 4$ & $1: 2$ & $3: 6$ & $1: 4$ & $1: 6$ \\
\hline Sodium Starch Glycolate $(\mathrm{mg})$ & 20 & 20 & 20 & 20 & 20 \\
\hline PEG 400 (ml) & 0.4 & 0.4 & 0.4 & 0.4 & 0.4 \\
\hline Aspartame (mg) & 30 & 30 & 30 & 30 & 30 \\
\hline Citric acid (mg) & 20 & 20 & 20 & 20 & 20 \\
\hline Orange oil (ml) & Q.S & Q.S & Q.S & Q.S & Q.S \\
\hline Ethanol (ml) & Q.S & Q.S & Q.S & Q.S & Q.S \\
\hline Distilled water (ml) & Q.S & Q.S & Q.S & Q.S & Q.S \\
\hline
\end{tabular}

Table 2: Concentration vs Absorbance data of Ramipril

\begin{tabular}{|c|c|}
\hline $\begin{array}{c}\text { Concentration } \\
(\mu \mathrm{g} / \mathrm{ml})\end{array}$ & Absorbance $(\mathbf{n m})$ \\
\hline 0 & 0 \\
\hline 2 & $0.106 \pm 0.02$ \\
\hline 4 & $0.205 \pm 0.04$ \\
\hline 6 & $0.300 \pm 0.05$ \\
\hline 8 & $0.399 \pm 0.08$ \\
\hline 10 & $0.490 \pm 0.06$ \\
\hline
\end{tabular}


Table 3: Comparision study of FTIR spectrum of Ramipril pure drug and optimized formulation E2

\begin{tabular}{|c|c|c|c|c|}
\hline \multirow{2}{*}{ S.No } & \multirow{2}{*}{ Functional group } & $\begin{array}{c}\text { Standard wave } \\
\text { number }\left(\mathbf{c m}^{-1}\right)\end{array}$ & \multicolumn{2}{|c|}{ Test wave number $\mathbf{( c m}^{-1} \mathbf{)}$} \\
\cline { 4 - 5 } & & Drug & E2 \\
\hline 1. & $\mathrm{Ar}-\mathrm{H}$ (Aromatic) & $3050-3000$ & 3042.96 & 3042.96 \\
\hline 2. & $\mathrm{C}-\mathrm{H}$ (Aliphatic) & $2960-2850$ & 2947.82 & 2947.82 \\
\hline 3. & $\mathrm{C}=\mathrm{O}$ (Ester) & $1750-1735$ & 1741.58 & 1741.58 \\
\hline 4. & $\mathrm{C}-\mathrm{O}$ (Ether) & $1150-1070$ & 1183.72 & 1183.72 \\
\hline
\end{tabular}

Table 4: Comparative Physical properties of film formulations

\begin{tabular}{|c|c|c|c|c|}
\hline $\begin{array}{c}\text { Formulatio } \\
\mathbf{n} \text { code }\end{array}$ & $\begin{array}{c}\text { Weight } \\
\text { uniformity(mg) } \mathbf{m} \\
\text { S.D; } \mathbf{n = 1 0}\end{array}$ & $\begin{array}{c}\text { Thickness }(\boldsymbol{\mu m}) \mathbf{\pm} \\
\text { S.D; } \mathbf{n = 3}\end{array}$ & $\begin{array}{c}\text { Folding } \\
\text { endurance } \mathbf{\pm} \text { S.D; } \\
\mathbf{n = 3}\end{array}$ & $\begin{array}{c}\text { Surface } \mathbf{p H} \pm \\
\text { S.D; } \mathbf{n}=\mathbf{3}\end{array}$ \\
\hline E1 & $28.7 \pm 0.20$ & $90 \pm 2$ & $297 \pm 1$ & $6.65 \pm 0.06$ \\
\hline E2 & $22.5 \pm 0.30$ & $80 \pm 1$ & $300 \pm 1$ & $6.88 \pm 0.02$ \\
\hline E3 & $32 \pm 0.60$ & $95 \pm 2.5$ & $298 \pm 2$ & $6.64 \pm 0.05$ \\
\hline E4 & $25.6 \pm 0.30$ & $84 \pm 1$ & $291 \pm 2$ & $6.58 \pm 0.08$ \\
\hline E5 & $29.8 \pm 0.04$ & $88 \pm 2$ & $296 \pm 2$ & $6.68 \pm 0.7$ \\
\hline
\end{tabular}

Table 5: Comparative Physical properties of film formulations

\begin{tabular}{|c|c|c|c|}
\hline $\begin{array}{c}\text { Formulation } \\
\text { code }\end{array}$ & $\begin{array}{c}\text { Percent moisture absorption } \\
(\%) \pm \mathbf{S . D} ; \mathbf{n}=\mathbf{3}\end{array}$ & $\begin{array}{c}\text { Percent moisture loss } \\
(\%) \pm \mathbf{S . D} ; \mathbf{n = 3}\end{array}$ & $\begin{array}{c}\text { Swelling index } \mathbf{\text { S.D; }} \\
\mathbf{n = 3}\end{array}$ \\
\hline $\mathrm{E} 1$ & $2.4 \pm 0.02$ & $1.5 \pm 0.02$ & $12 \pm 0.10$ \\
\hline $\mathrm{E} 2$ & $0.5 \pm 0.01$ & $0.5 \pm 0.01$ & $16.9 \pm 0.03$ \\
\hline $\mathrm{E} 3$ & $2.3 \pm 0.03$ & $2 \pm 0.02$ & $12.2 \pm 0.06$ \\
\hline $\mathrm{E} 4$ & $1.3 \pm 0.02$ & $1.5 \pm 0.02$ & $15.7 \pm 0.05$ \\
\hline $\mathrm{E} 5$ & $1 \pm 0.02$ & $1 \pm 0.02$ & $14.4 \pm 0.03$ \\
\hline
\end{tabular}

Table 6: In-vitro disintegration time and Drug content uniformity profile of all formulations (E1-E5)

\begin{tabular}{|c|c|c|c|}
\hline S.No & $\begin{array}{c}\text { Formulation } \\
\text { code }\end{array}$ & $\begin{array}{c}\text { In-vitro disintegration } \\
\text { time }(\mathbf{s e c}) \pm \text { S.D; } \mathbf{n = 3}\end{array}$ & $\begin{array}{c}\text { Drug content } \\
\text { uniformity } \pm \text { S.D; } \mathbf{n}=\mathbf{3}\end{array}$ \\
\hline 1. & $\mathrm{E} 1$ & $30 \pm 0.08$ & $95.5 \pm 0.03$ \\
\hline 2. & $\mathrm{E} 2$ & $20 \pm 0.07$ & $98.2 \pm 0.03$ \\
\hline 3. & $\mathrm{E} 3$ & $33 \pm 0.10$ & $94 \pm 0.04$ \\
\hline 4. & $\mathrm{E} 4$ & $28 \pm 0.04$ & $94.8 \pm 0.02$ \\
\hline 5. & $\mathrm{E} 5$ & $30 \pm 0.09$ & $93.3 \pm 0.04$ \\
\hline
\end{tabular}

Table 7: Based on the release profiles the order of drug release of formulations (E1-E5)

\begin{tabular}{|c|c|c|c|c|c|}
\hline Time (sec) & \multicolumn{5}{|c|}{ \% cumulative drug release (\%CDR) \pm S.D ; n=3 } \\
\hline & E1 & E2 & E3 & E4 & E5 \\
\hline 0 & 0 & 0 & 0 & 0 & 0 \\
\hline 20 & $20.4 \pm 0.30$ & $22.7 \pm 0.20$ & $20.2 \pm 0.28$ & $21.9 \pm 0.25$ & $20.8 \pm 0.22$ \\
\hline 40 & $28.4 \pm 0.35$ & $29.8 \pm 0.24$ & $28.3 \pm 0.22$ & $29.8 \pm 0.20$ & $31.8 \pm 0.25$ \\
\hline 60 & $46 \pm 0.46$ & $44.2 \pm 0.30$ & $44 \pm 0.29$ & $42.7 \pm 0.22$ & $44.7 \pm 0.30$ \\
\hline 80 & $53.2 \pm 0.39$ & $57.5 \pm 0.15$ & $54.9 \pm 0.21$ & $50.9 \pm 0.35$ & $52 \pm 0.32$ \\
\hline 100 & $64.8 \pm 0.04$ & $68.1 \pm 0.45$ & $66.3 \pm 0.65$ & $57 \pm 0.31$ & $61.1 \pm 0.25$ \\
\hline 120 & $70.9 \pm 0.15$ & $77.5 \pm 0.49$ & $70.6 \pm 0.22$ & $66.8 \pm 0.55$ & $65.3 \pm 0.33$ \\
\hline 140 & $77.5 \pm 0.20$ & $87.3 \pm 0.34$ & $75.8 \pm 0.25$ & $72.3 \pm 0.32$ & $73.5 \pm 0.29$ \\
\hline 160 & $84.7 \pm 0.40$ & $92.9 \pm 0.23$ & $85.2 \pm 0.78$ & $82.3 \pm 0.19$ & $85.7 \pm 0.20$ \\
\hline 180 & $90.2 \pm 0.54$ & $98.2 \pm 0.54$ & $89.5 \pm 0.43$ & $89.3 \pm 0.30$ & $91.7 \pm 0.25$ \\
\hline
\end{tabular}

Table 8: Stability studies of optimized formulation (E2)

\begin{tabular}{|c|c|c|c|}
\hline S.No & Days & $\begin{array}{c}\text { Drug content } \\
\text { uniformity }(\%) \pm \mathbf{S . D} ; \\
\mathbf{n = 3}\end{array}$ & $\begin{array}{c}\text { In-vitro disintegration } \\
\text { test (sec) } \pm \mathbf{S . D} ; \mathbf{n}=\mathbf{3}\end{array}$ \\
\hline 1. & Initial (0 days) & $96.2 \pm 0.02$ & $20 \pm 0.07$ \\
\hline 2. & 1 month (30days) & $96.2 \pm 0.05$ & $20 \pm 0.05$ \\
\hline 3. & 3 months (90days) & $96.2 \pm 0.03$ & $20 \pm 0.05$ \\
\hline
\end{tabular}


Table 9: In-vitro dissolution profile of optimized formulation (E2) after stability studies

\begin{tabular}{|c|c|c|}
\hline Time (sec) & $\begin{array}{c}\text { \% Cummulaative drug } \\
\text { release } \\
\text { before stability study } \\
\mathbf{\pm} \text { S.D; } \mathbf{n = 3}\end{array}$ & $\begin{array}{c}\text { \% Cummulaative drug } \\
\text { release after stability } \\
\text { study } \pm \text { S.D; } \mathbf{n = 3}\end{array}$ \\
\hline 0 & 0 & 0 \\
\hline 20 & $22.7 \pm 0.20$ & $22.5 \pm 0.23$ \\
\hline 40 & $29.8 \pm 0.24$ & $29.8 \pm 0.24$ \\
\hline 60 & $44 \pm 0.30$ & $44.2 \pm 0.29$ \\
\hline 80 & $57.5 \pm 0.15$ & $57.4 \pm 0.18$ \\
\hline 100 & $68.1 \pm 0.45$ & $68.1 \pm 0.42$ \\
\hline 120 & $77.5 \pm 0.49$ & $77 \pm 0.49$ \\
\hline 140 & $80.3 \pm 0.34$ & $80.3 \pm 0.33$ \\
\hline 160 & $94.9 \pm 0.23$ & $94.9 \pm 0.20$ \\
\hline 180 & $98.2 \pm 0.54$ & $98.2 \pm 0.54$ \\
\hline
\end{tabular}

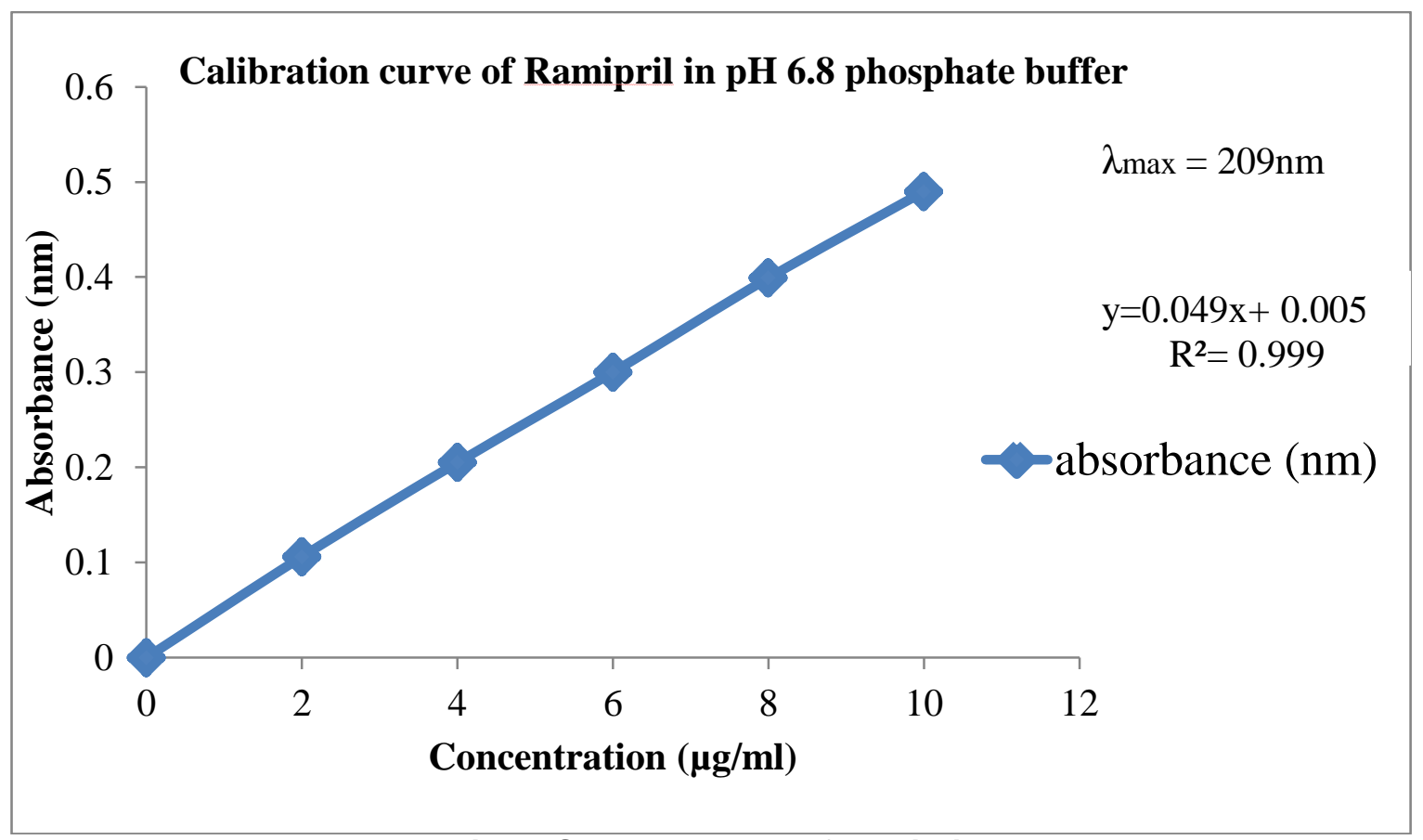

Fig. 1: Standard graph of Ramipril 


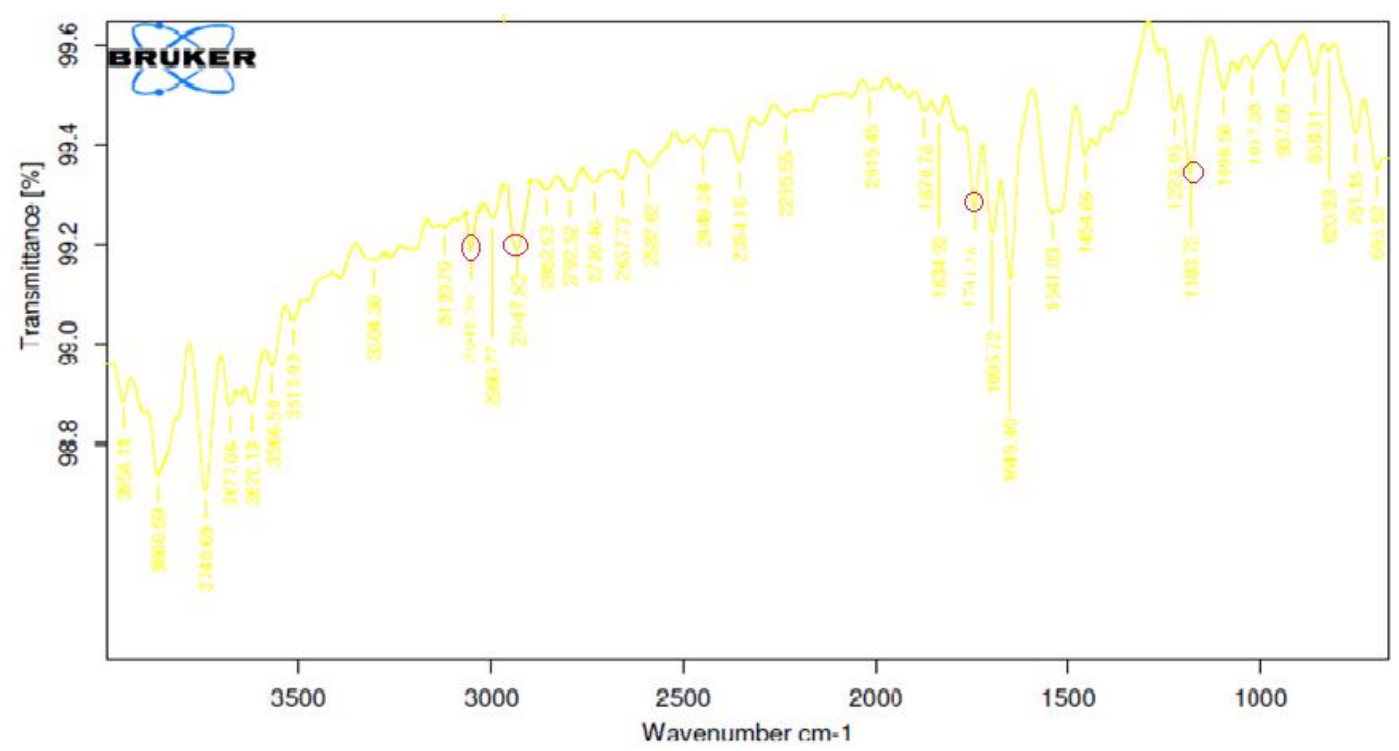

Fig. 2: FTIR Spectra of Ramipril

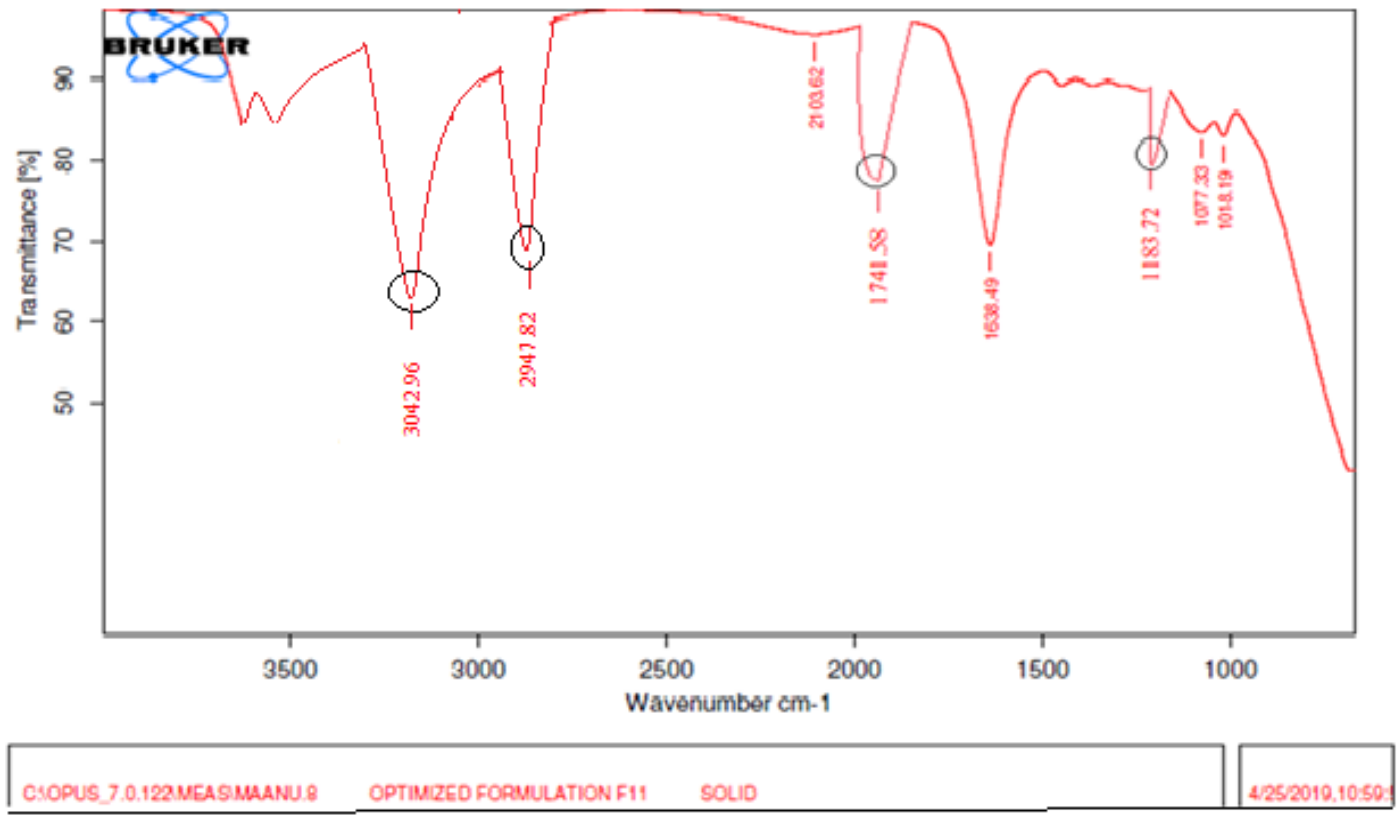

Fig. 3: FTIR Spectra of optimized formulation F2 


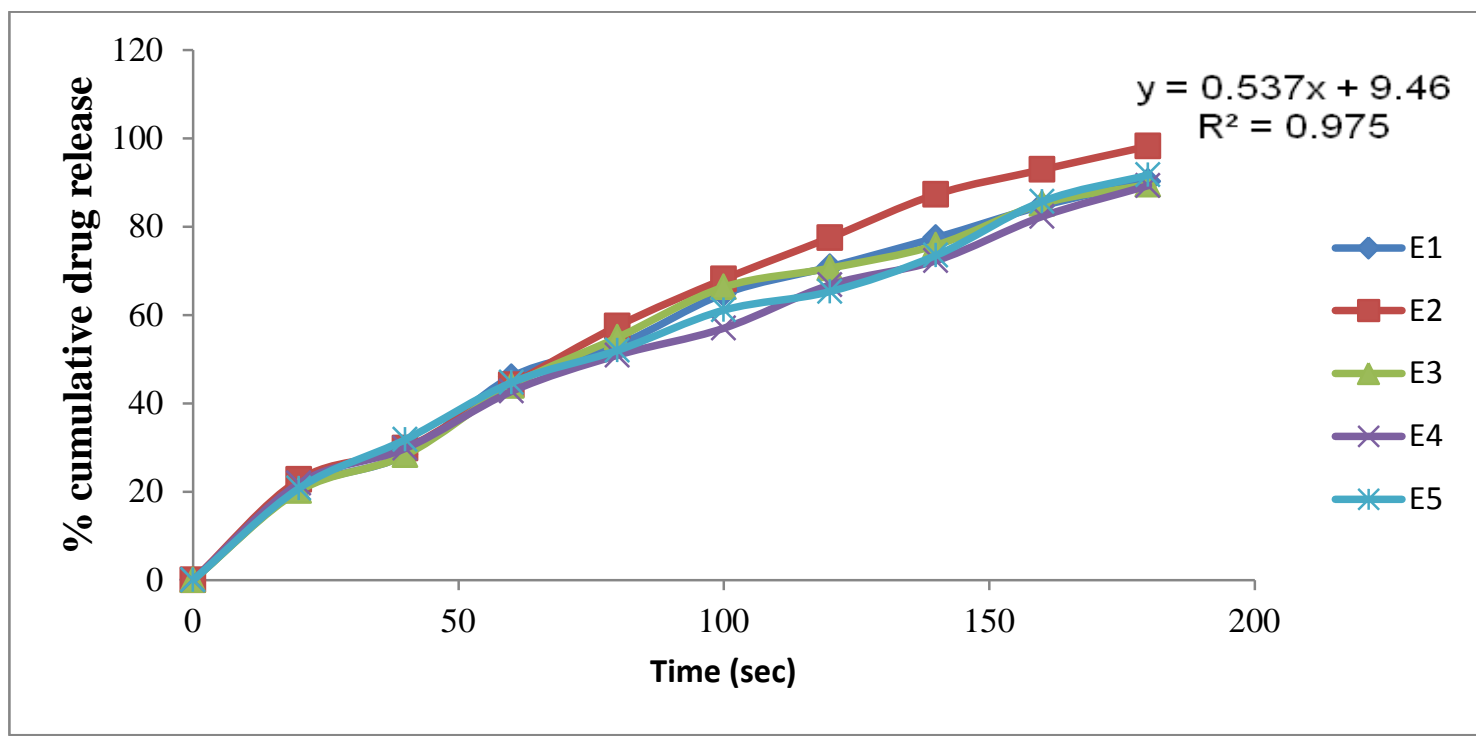

Fig. 4: Dissolution profile of all formulations (E1-E5)

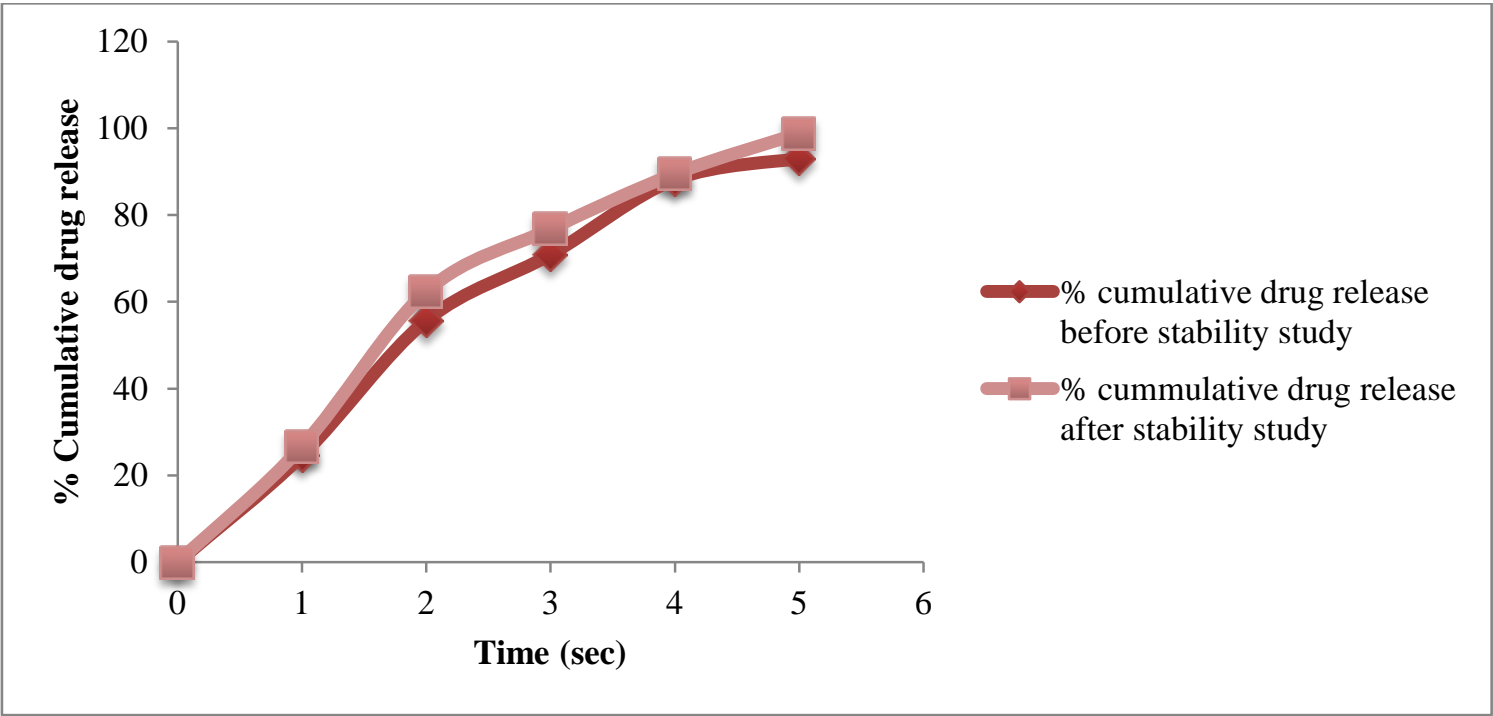

Fig. 5: Dissolution profile of optimized formulation E2 after stability studies

\section{REFERENCES}

1. Deepak Sharma, Daljit Kaur, Shivani Verma, Davinder Singh, Mandeep Singh, Gurmeet Singh and Rajeev Garg. Fast Dissolving Oral Films Technology: A Recent Trend for an Innovative Oral Drug Delivery System. International Journal of Drug Delivery. 2015;(7):60-75.

2. Anjana anil and Preethi Sudheer. International Journal of Pharmaceutical Sciences. 2018; (2):121-129.

3. Rajini Bala, Pravin Pawar, Sushil Khanna and Sandeep Arora. Orally dissolving strips: A new approach to oral drug delivery system. International Journal of PharmTech Research. 2012;(2).

4. Anusha J, Prasanna MR, Jyothi P and Lakshmana Rao A. Indian Journal of Pharmacy and Pharmacology. 2016;3(4):221-224.

5. Alpesh R Patel, Dharmendra $S$ Prajapati and Jignyasha A Raval. Fast dissolving films (FDFs) as a newer venture in fast dissolving dosage forms, International Journal of Drug Development and Research. 2010;(2). 
6. Puja Chaurasiya, Rajesh Kharel, Manasa Deepa R, Rajashekhar V and Sridhar KA. Review on Oral Fast Dissolving Films A Novel Drug Delivery System, Asian Journal of Research in Chemistry and Pharmaceutical Sciences. 2016;(4):165-175.

7. Udupa N, Chonkar Ankitha D and Bhagawati ST. An overview on fast dissolving oral films, Assian Journal Pharmaceutical 2015;(5):129-137.

8. Ramani Gade, Aparna Ayunampudi, Anitha Makineni, Murthy TEGK,
Chandu Babu Rao and Sreekanth Nama. Design and Development of Pravastatin sodium Fast Dissolving Films from natural mucilage of Ocimum bacilicum seeds, International Journal of Pharma Research and Review. 2014;17-27.

9. Nitesh S Chauhan, Alka Tomar, Kiran Sharma and Ashu Mittal. Umakant Formulation and Evaluation of fast dissolving oral film of Dicyclomine as potent route of buccal delivery. International Journal of Drug Development and Research. IJDDR. 2011;(2):408-417. 